Article

\title{
Labdane Diterpenes from the Fruits of Sinopodophyllum emodi
}

\author{
Yan-Jun Sun ${ }^{1,2, *}$, Mei-Ling Gao ${ }^{1,2}$, Yan-Li Zhang ${ }^{1,2}$, Jun-Min Wang ${ }^{1,2}$, Ya Wu ${ }^{1,2}$, Yu Wang ${ }^{3}$ \\ and Tao $\mathrm{Liu}^{3, *}$ \\ 1 Collaborative Innovation Center for Respiratory Disease Diagnosis and Treatment \& Chinese Medicine \\ Development of Henan Province, Henan University of Traditional Chinese Medicine, Zhengzhou 450046, \\ Henan, China; gaoxiaomei6266@126.com (M.-L.G.); zyl2013hnzy@163.com (Y.-L.Z.); \\ wjmhnzz@163.com (J.-M.W.); wuya0723@126.com (Y.W.) \\ 2 School of Pharmacy, Henan University of Traditional Chinese Medicine, Zhengzhou 450046, Henan, China \\ 3 School of Pharmacy, China Medical University, Shenyang 110122, Liaoning, China; xiaowangyu21@163.com \\ * Correspondence: sunyanjun2011@hactcm.edu.cn (Y.-J.S.); taoliu0307@163.com (T.L.); \\ Tel./Fax: +86-371-6596-2746 (Y.-J.S. \& T.L.)
}

Academic Editors: Quan-Bin Han and Jian-Xin Pu

Received: 3 March 2016; Accepted: 24 March 2016; Published: 31 March 2016

\begin{abstract}
Two new labdane diterpenes, sinoditerpene A (1) and B (2), were isolated from the fruits of Sinopodophyllum emodi, along with two known analogues 3 and 4 . Their structures were established on the basis of extensive spectroscopic analysis. The isolation of compounds 1-4 represents the first report of diterpenes from the genus Sinopodophyllum. The cytotoxic activities of all isolated compounds were evaluated in comparison with 5-fluorouracil against the MCF-7 and HepG2 cell lines, towards which 3 showed more potent cytotoxicity.
\end{abstract}

Keywords: Sinopodophyllum emodi; labdane diterpene; cytotoxic activity

\section{Introduction}

Sinopodophyllum emodi is an important medicinal plant that has been described in the Chinese Pharmacopoeia and Tibetan medicine [1]. Its dried roots and rhizomes (called Taoerqi in Chinese) are frequently used for the treatment of certain cancers, various verrucosis [2], constipation, verminosis [3], rheumatoid pain [4], and pyogenic skin tissue infections [5]. The dried ripe fruits (called "Xiaoyelian" in Chinese) are clinically applied to the treatment of amenorrhea, dead fetus, and placental retention [1]. Previous phytochemical and pharmacological investigations revealed that $S$. emodi is particularly rich in aryltetralin lactone lignans and prenylated flavonoids, and has attracted wide attention due to their cytotoxic properties [1-3,6-9]. In our search for cytotoxic natural products, we previously reported the isolation, identification and cytotoxic activity of aryltetralin lactone and tetrahydrofuranoid lignans, and prenylated flavonoids from S. emodi [10-12]. In a further examination of the fruits of this plant, two new labdane diterpenes, sinoditerpene A (1) and B (2), were obtained together with two known analogues 3 and 4 (Figure 1). For the first time, the NMR signals for compound 4 were completely assigned by 2D NMR spectra $\left({ }^{1} \mathrm{H}-{ }^{1} \mathrm{H}\right.$ COSY, HSQC, HMBC, NOESY). Details of the isolation, structure elucidation, and cytotoxicity of all isolated compounds against MCF-7 and HepG2 cell lines are described here. 


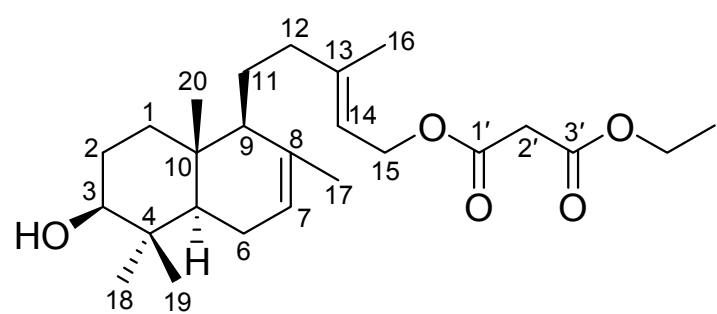

1<smiles>[3H]C1=CCC2[C@@H](C)[C@H](O)CC[C@]2(C)[C@@H]1CC/C(C)=C/COC(=O)C[C@](O)(CC(=O)OCC)C(=O)OCC</smiles>

2<smiles>CC1=CC[C@H]2[C@@H](C)[C@@H](O)CC[C@]2(C)[C@H]1CC/C(C)=C/CO</smiles>

3

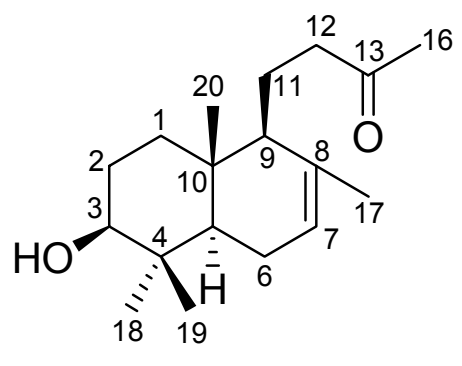

4

Figure 1. The chemical structures of compounds 1-4 from S. emodi.

\section{Results and Discussion}

The EtOH extract of the fruits of Sinopodophyllum emodi was partitioned between $\mathrm{PE}, \mathrm{CH}_{2} \mathrm{Cl}_{2}$, EtOAc, $n-\mathrm{BuOH}$ and water, respectively. The $\mathrm{CH}_{2} \mathrm{Cl}_{2}$ layer was fractionated and purified by repeated column chromatography, allowing the isolation of four labdane diterpenes 1-4. By comparing their physical and spectroscopic data $\left({ }^{1} \mathrm{H}-\mathrm{NMR},{ }^{13} \mathrm{C}-\mathrm{NMR},{ }^{1} \mathrm{H}-{ }^{1} \mathrm{H}\right.$ COSY, HSQC, HMBC, and NOESY in Supplementary Materials) with literature values [13], the two known metabolites were identified as labda-7,13-diene-3,15-diol (3) and 14,15-dinor-3 $\beta$-hydroxy-7-labden-13-one (4). The chemical structures of two new labdane diterpenes were determined on the basis of spectroscopic evidences $\left({ }^{1} \mathrm{H}-\mathrm{NMR}\right.$, ${ }^{13} \mathrm{C}-\mathrm{NMR},{ }^{1} \mathrm{H}-{ }^{1} \mathrm{H}$ COSY, HSQC, HMBC, DEPT, and NOESY in Supplementary Materials), and their absolute configurations were elucidated by $[\alpha]_{D}$ and NOESY analysis.

Compound 1 was obtained as a sticky oil and possessed a molecular formula $\mathrm{C}_{25} \mathrm{H}_{40} \mathrm{O}_{5}$ with six degrees of unsaturation, as revealed from its HR-ESI-MS analysis $\left(m / z 443.2771[\mathrm{M}+\mathrm{Na}]^{+}\right.$, calcd 443.2773). The IR spectrum displayed the presence of carbonyl $\left(1736 \mathrm{~cm}^{-1}\right)$ and hydroxy $\left(3464 \mathrm{~cm}^{-1}\right)$ groups. The ${ }^{13} \mathrm{C}-\mathrm{NMR}$ and DEPT spectra showed twenty-five carbon signals, including six quaternary carbons, six methyls, eight methylenes and five methines. The ${ }^{1} \mathrm{H}-$ and ${ }^{13} \mathrm{C}-\mathrm{NMR}$ spectra (Tables 1 and 2) revealed the presence of malonic acid monoethyl ester [14] and a labdane skeleton $[13,15,16]$. One oxygenated methylene $\left[\delta_{\mathrm{H}} 4.18(2 \mathrm{H}, \mathrm{q}, J=7.2 \mathrm{~Hz}), \delta_{\mathrm{C}} 62.3\right]$, one methyl $\left[\delta_{\mathrm{H}} 1.26(3 \mathrm{H}, \mathrm{t}, J=7.2 \mathrm{~Hz})\right.$, $\left.\delta_{\mathrm{C}} 14.1\right]$, one methylene $\left[\delta_{\mathrm{H}} 3.22(2 \mathrm{H}, \mathrm{s}), \delta_{\mathrm{C}} 41.7\right]$, and two ester carbonyls $\left[\delta_{\mathrm{C}} 166.7,166.6\right]$ were observed, suggesting the presence of malonic acid monoethyl ester [14]. Two ester carbonyl $\left[\delta_{C} 166.7\right.$, 166.6], and four olefinic carbons $\delta_{C} 117.9,122.3,135.0,143.3$ accounted for four out of the six degrees of unsaturation, and the remaining two indicated that compound 1 was bicyclic. Five methyls $\left[\delta_{\mathrm{H}}\right.$ $0.74(3 \mathrm{H}, \mathrm{s}), 0.83(3 \mathrm{H}, \mathrm{s}), 0.95(3 \mathrm{H}, \mathrm{s}), 1.67$ (3H, br.s), $\left.1.70(3 \mathrm{H}, \mathrm{br} . \mathrm{s}), \delta_{\mathrm{C}} 13.6,15.0,16.6,21.9,27.9\right]$, six methylenes [one oxygenated $\delta_{\mathrm{H}} 4.64(2 \mathrm{H}, \mathrm{d}, J=7.2 \mathrm{~Hz}), \delta_{\mathrm{C}} 61.5$ ], five methine [one oxygenated $\delta_{\mathrm{H}} 3.22(1 \mathrm{H}, \mathrm{dd}, J=11.2,4.5 \mathrm{~Hz}), \delta_{\mathrm{C}} 79.1$; two olefinic $\left.\delta_{\mathrm{H}} 5.38(1 \mathrm{H}, \mathrm{br} . \mathrm{s}), 5.32(1 \mathrm{H}, \mathrm{t}, J=7.2 \mathrm{~Hz})\right]$, and four olefinic carbons $\left[\delta_{C} 117.9,122.3,135.0,143.3\right]$, suggested that compound 1 possessed a 3,15-dihydroxy-7,13-labdadien skeleton [13]. The HMBC correlation (Figure 2) between the ester carbonyl $\delta_{\mathrm{C}} 166.7\left(\mathrm{C}-1^{\prime}\right)$ and the methylene $\delta_{\mathrm{H}} 4.64(2 \mathrm{H}, \mathrm{d}, J=7.2 \mathrm{~Hz}, \mathrm{H}-15)$, indicated that the $15-\mathrm{OH}$ was esterified by malonic acid monoethyl ester.

The relative configuration of the ring substituents of compound $\mathbf{1}$ was determined by analyzing the NOESY spectrum (Figure 3). The NOESY correlations from H-3 to Me-18, H-5, and H-1 $\alpha$ indicated that they were cofacial and were assigned $\alpha$-orientation. The NOESY cross peak of Me-19/Me-20 
and Me-20/H-11 showed that these protons were $\beta$-oriented. Additionally, the stereochemistry of the side-chain double bond was established as $E$ by virtue of the Me-16 chemical shifts $\left(\delta_{\mathrm{H}} 1.70\right.$; $\delta_{C}$ 16.6) [13]. This was also supported by the cross peak of $\mathrm{H}-12 / \mathrm{H}-14$ in the NOESY spectrum. The absolute configuration is the same as (-)-labda-7,13-diene-3,15-diol [17,18], which was determined by a microhydrolysis method and comparison of $[\alpha]_{D}$ values. Thus, compound 1 was established as 3ß-hydroxy-15-(3'-ethoxy-3'-oxopropionyloxy)-7,13E-labdadiene, and named sinoditerpene A.

Table 1. ${ }^{1} \mathrm{H}-\mathrm{NMR}$ data $\left(500 \mathrm{MHz}, \delta\right.$ in ppm, $J$ in $\mathrm{Hz}$ ) of compounds $1-4$ in $\mathrm{CDCl}_{3}$.

\begin{tabular}{ccccc}
\hline No. & $\mathbf{1}$ & $\mathbf{2}$ & $\mathbf{3}$ & $\mathbf{4}$ \\
\hline 1 & $1.07(1 \mathrm{H}, \mathrm{td}, 13.2,4.2)$ & $1.06(1 \mathrm{H}, \mathrm{td}, 13.1,4.5)$ & $1.06(1 \mathrm{H}, \mathrm{td}, 13.2,4.4)$ & $1.10(1 \mathrm{H}, \mathrm{td}, 13.3,4.0)$ \\
2 & $1.84(1 \mathrm{H}, \mathrm{dt}, 13.2,3.4)$ & $1.84(1 \mathrm{H}, \mathrm{dt}, 13.1,3.4)$ & $1.84(1 \mathrm{H}, \mathrm{dt}, 13.2,3.4)$ & $1.91(1 \mathrm{H}, \mathrm{dt}, 13.3,3.6)$ \\
3 & $1.60(2 \mathrm{H}, \mathrm{m})$ & $1.60(2 \mathrm{H}, \mathrm{m})$ & $1.60(2 \mathrm{H}, \mathrm{m})$ & $1.60(2 \mathrm{H}, \mathrm{m})$ \\
5 & $3.22(1 \mathrm{H}, \mathrm{dd}, 11.2,4.5)$ & $3.22(1 \mathrm{H}, \mathrm{dd}, 11.0,4.8)$ & $3.20(1 \mathrm{H}, \mathrm{dd}, 11.2,4.5)$ & $3.21(1 \mathrm{H}, \mathrm{dd}, 11.4,4.4)$ \\
6 & $1.16(1 \mathrm{H}, \mathrm{dd}, 10.9,6.1)$ & $1.17(1 \mathrm{H}, \mathrm{dd}, 10.9,6.1)$ & $1.15(1 \mathrm{H}, \mathrm{dd}, 10.9,6.1)$ & $1.15(1 \mathrm{H}, \mathrm{dd}, 10.9,6.1)$ \\
7 & $1.95(2 \mathrm{H}, \mathrm{m})$ & $1.95(2 \mathrm{H}, \mathrm{m})$ & $1.95(2 \mathrm{H}, \mathrm{m})$ & $1.95(2 \mathrm{H}, \mathrm{m})$ \\
9 & $5.38(1 \mathrm{H}, \mathrm{br.s})$ & $5.38(1 \mathrm{H}, \mathrm{br} . \mathrm{s})$ & $5.37(1 \mathrm{H}, \mathrm{br} . \mathrm{s})$ & $5.39(1 \mathrm{H}, \mathrm{br} . \mathrm{s})$ \\
& $1.57(1 \mathrm{H}, \mathrm{m})$ & $1.58(1 \mathrm{H}, \mathrm{m})$ & $1.58(1 \mathrm{H}, \mathrm{m})$ & $1.57(1 \mathrm{H}, \mathrm{m})$ \\
11 & $1.47(1 \mathrm{H}, \mathrm{m})$ & $1.50(1 \mathrm{H}, \mathrm{m})$ & $1.50(1 \mathrm{H}, \mathrm{m})$ & $1.78(1 \mathrm{H}, \mathrm{m})$ \\
& $1.25(1 \mathrm{H}, \mathrm{m})$ & $1.25(1 \mathrm{H}, \mathrm{m})$ & $1.28(1 \mathrm{H}, \mathrm{m})$ & $1.45(1 \mathrm{H}, \mathrm{m})$ \\
12 & $1.95(1 \mathrm{H}, \mathrm{m})$ & $1.95(1 \mathrm{H}, \mathrm{m})$ & $1.95(1 \mathrm{H}, \mathrm{m})$ & $2.40(1 \mathrm{H}, \mathrm{m})$ \\
14 & $2.22(1 \mathrm{H}, \mathrm{m})$ & $2.20(1 \mathrm{H}, \mathrm{m})$ & $2.20(1 \mathrm{H}, \mathrm{m})$ & $2.63(1 \mathrm{H}, \mathrm{m})$ \\
15 & $5.32(1 \mathrm{H}, \mathrm{t}, 7.2)$ & $5.32(1 \mathrm{H}, \mathrm{t}, 7.5)$ & $5.40(1 \mathrm{H}, \mathrm{t}, 7.0)$ & \\
16 & $4.64(2 \mathrm{H}, \mathrm{d}, 7.2)$ & $4.58(2 \mathrm{H}, \mathrm{d}, 7.5)$ & $4.13(2 \mathrm{H}, \mathrm{d}, 7.0)$ & $2.11(3 \mathrm{H}, \mathrm{s})$ \\
17 & $1.70(3 \mathrm{H}, \mathrm{s})$ & $1.68(3 \mathrm{H}, \mathrm{s})$ & $1.67(3 \mathrm{H}, \mathrm{s})$ & $0.94(3 \mathrm{H}, \mathrm{s})$ \\
18 & $1.67(3 \mathrm{H}, \mathrm{s})$ & $1.68(3 \mathrm{H}, \mathrm{s})$ & $1.66(3 \mathrm{H}, \mathrm{s})$ & $0.83(3 \mathrm{H}, \mathrm{s})$ \\
19 & $0.95(3 \mathrm{H}, \mathrm{s})$ & $0.95(3 \mathrm{H}, \mathrm{s})$ & $0.94(3 \mathrm{H}, \mathrm{s})$ & $0.76(3 \mathrm{H}, \mathrm{s})$ \\
20 & $0.83(3 \mathrm{H}, \mathrm{s})$ & $0.83(3 \mathrm{H}, \mathrm{s})$ & $0.83(3 \mathrm{H}, \mathrm{s})$ & \\
& $0.74(3 \mathrm{H}, \mathrm{s})$ & $0.73(3 \mathrm{H}, \mathrm{s})$ & $0.73(3 \mathrm{H}, \mathrm{s})$ & \\
$2^{\prime}$ & $3.22(2 \mathrm{H}, \mathrm{s})$ & $2.76(1 \mathrm{H}, \mathrm{d}, 15.6)$ & & \\
& & $2.87(1 \mathrm{H}, \mathrm{d}, 15.6)$ & & \\
$4^{\prime}$ & & $2.76(1 \mathrm{H}, \mathrm{d}, 15.6)$ & & \\
$\mathrm{CH}_{2}$ & $4.18(2 \mathrm{H}, \mathrm{q}, 7.2)$ & $2.87(1 \mathrm{H}, \mathrm{d}, 15.6)$ & & \\
$\mathrm{CH}_{3}$ & $1.26(3 \mathrm{H}, \mathrm{t}, 7.2)$ & $1.12(2 \mathrm{H}, \mathrm{q}, 7.2)$ & & \\
$\mathrm{CH}_{2}$ & & $4.26(3 \mathrm{H}, \mathrm{t}, 7.2)$ & & \\
$\mathrm{CH}_{3}$ & & $1.26(3 \mathrm{H}, \mathrm{t}, 7.2)$ & & \\
\hline
\end{tabular}

Table 2. ${ }^{13} \mathrm{C}-\mathrm{NMR}$ data $\left(125 \mathrm{MHz}, \delta\right.$ in ppm) of compounds $1-4$ in $\mathrm{CDCl}_{3}$.

\begin{tabular}{llllllllll}
\hline No. & $\mathbf{1}$ & $\mathbf{2}$ & $\mathbf{3}$ & $\mathbf{4}$ & $\mathbf{N o .}$ & $\mathbf{1}$ & $\mathbf{2}$ & $\mathbf{3}$ & $\mathbf{4}$ \\
\hline 1 & 37.2 & 37.2 & 37.1 & 37.4 & 16 & 16.6 & 16.6 & 16.5 & 30.0 \\
2 & 27.3 & 27.4 & 27.3 & 27.4 & 17 & 21.9 & 21.9 & 21.9 & 22.0 \\
3 & 79.1 & 79.1 & 79.1 & 79.1 & 18 & 27.9 & 27.9 & 27.8 & 27.9 \\
4 & 38.6 & 38.6 & 38.6 & 38.7 & 19 & 15.0 & 15.0 & 15.0 & 15.1 \\
5 & 49.5 & 49.5 & 49.5 & 49.5 & 20 & 13.6 & 13.6 & 13.6 & 13.6 \\
6 & 23.4 & 23.4 & 23.4 & 23.4 & $1^{\prime}$ & 166.7 & 169.80 & & \\
7 & 122.3 & 122.3 & 122.1 & 122.9 & $2^{\prime}$ & 41.7 & 43.2 & & \\
8 & 135.0 & 135.0 & 135.1 & 134.3 & $3^{\prime}$ & 166.6 & 73.2 & & \\
9 & 54.3 & 54.2 & 54.3 & 54.3 & $4^{\prime}$ & & 43.3 & & \\
10 & 36.6 & 36.6 & 36.6 & 36.7 & $5^{\prime}$ & & 169.76 & & \\
11 & 25.5 & 25.3 & 25.5 & 20.8 & $6^{\prime}$ & & 173.4 & & \\
12 & 41.9 & 41.8 & 41.9 & 45.7 & $\mathrm{CH}_{2}$ & 62.3 & 62.3 & & \\
13 & 143.3 & 143.2 & 140.0 & 208.7 & $\mathrm{CH}_{3}$ & 14.1 & 14.0 & & \\
14 & 117.9 & 118.0 & 123.5 & & $\mathrm{CH}_{2}$ & & 61.0 & & \\
15 & 61.5 & 61.8 & 59.4 & & $\mathrm{CH}_{3}$ & & 14.1 & & \\
\hline
\end{tabular}




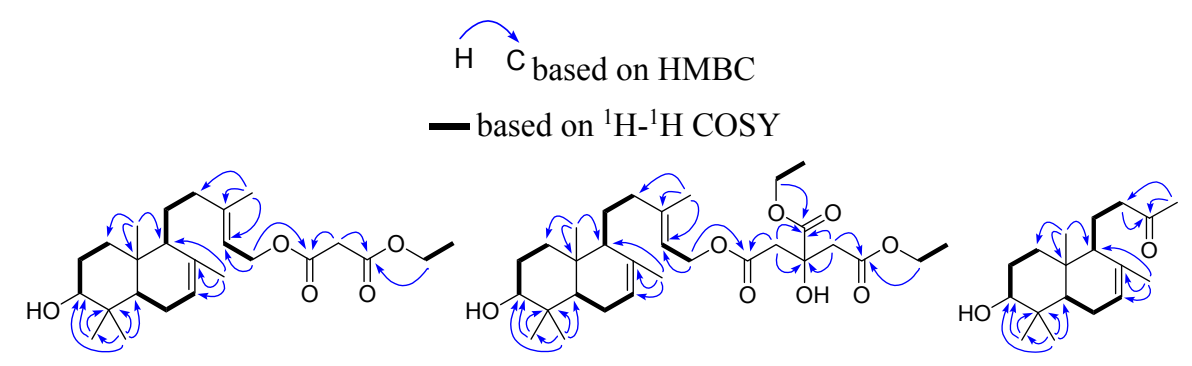

Figure 2. Key ${ }^{1} \mathrm{H}^{-1} \mathrm{H}$ COSY, HMBC correlations of compounds 1-3.


Figure 3. Key NOESY correlations of compounds 1-3.

Compound 2 was obtained as a sticky oil and possessed a molecular formula $\mathrm{C}_{30} \mathrm{H}_{48} \mathrm{O}_{8}$ with seven degrees of unsaturation, as revealed from its HR-ESI-MS analysis $\left(m / z 559.3249[\mathrm{M}+\mathrm{Na}]^{+}\right.$, calcd 559.3247). The IR spectrum displayed the presence of carbonyl $\left(1734,1718 \mathrm{~cm}^{-1}\right)$ and hydroxyl $\left(3465 \mathrm{~cm}^{-1}\right)$ groups. Its ${ }^{1} \mathrm{H}$ - and ${ }^{13} \mathrm{C}-\mathrm{NMR}$ data (Tables 1 and 2 ) were quite similar to those of compound $\mathbf{1}$, except that citric acid-1,2-diethyl ester was observed instead of the malonic acid monoethyl ester of compound 1 . Two hydroxymethyls $\left[\delta_{\mathrm{H}} 4.12(2 \mathrm{H}, \mathrm{q}, J=7.2 \mathrm{~Hz}), 4.26(2 \mathrm{H}, \mathrm{q}, J=7.2 \mathrm{~Hz}), \delta_{\mathrm{C}} 61.0,62.3\right]$, two methyls [ $\delta_{\mathrm{H}} 1.26(3 \mathrm{H}$, $\left.\mathrm{t}, J=7.2 \mathrm{~Hz}), 1.28(3 \mathrm{H}, \mathrm{t}, J=7.2 \mathrm{~Hz}), \delta_{\mathrm{C}} 14.0,14.1\right]$, two methylenes $\left[\delta_{\mathrm{H}} 2.76(1 \mathrm{H}, \mathrm{d}, J=15.6 \mathrm{~Hz}), 2.87(1 \mathrm{H}\right.$, $\left.\mathrm{d}, J=15.6 \mathrm{~Hz}), 2.76(1 \mathrm{H}, \mathrm{d}, J=15.6 \mathrm{~Hz}), 2.87(1 \mathrm{H}, \mathrm{d}, J=15.6 \mathrm{~Hz}), \delta_{\mathrm{C}} 43.2,43.3\right]$, and three ester carbonyls $\left[\delta_{C} 169.76,169.80,173.4\right]$ were observed, suggesting the presence of citric acid-1,2-diethyl ester [19]. The HMBC correlation between the ester carbonyl $\delta_{\mathrm{C}} 169.80\left(\mathrm{C}-1^{\prime}\right)$ and the methylene $\delta_{\mathrm{H}} 4.58(2 \mathrm{H}, \mathrm{d}, J=7.5 \mathrm{~Hz}$, $\mathrm{H}-15)$, indicated that the $15-\mathrm{OH}$ was esterified by citric acid-1,2-diethyl ester. Thus, compound 2 was established as 3ß-hydroxy-15-[(3'-hydroxy-3', 4'-bis(ethoxycarbonyl)-butyroxy)]-7,13E-labdadiene, and named sinoditerpene $B$.

Compound 4 was obtained as a sticky oil and possessed a molecular formula $\mathrm{C}_{18} \mathrm{H}_{30} \mathrm{O}_{2}$ with four degrees of unsaturation, as revealed from its HR-ESI-MS analysis $\left(m / z 301.2148\left[\mathrm{M}+\mathrm{Na}^{+}\right.\right.$, calcd 301.2143). The IR spectrum displayed the presence of carbonyl $\left(1714 \mathrm{~cm}^{-1}\right)$ and hydroxy $\left(3415 \mathrm{~cm}^{-1}\right)$ groups. Its ${ }^{1} \mathrm{H}$ - and ${ }^{13} \mathrm{C}-\mathrm{NMR}$ (Tables 1 and 2) were similar to those of compound 3 , except that a carbonyl group $\delta_{C} 208.7$ were observed instead of two olefinic carbons $\delta_{C} 140.0$, 123.5 , and one oxygenated methylene $\delta_{C} 59.4$ in 1 . Due to apparent differences of carbon signal number in 4 (20 carbons) and 3 (18 carbons), it was reasonably assumed that 4 was a dinor-derivative of 3. The HMBC correlation between the carbonyl group $\delta_{\mathrm{C}} 208.7$ (C-13) and the methyl $\delta_{\mathrm{H}} 2.11$ $(3 \mathrm{H}, \mathrm{s}, \mathrm{H}-16)$, the methylene $\delta_{\mathrm{H}} 2.40(1 \mathrm{H}, \mathrm{m}, \mathrm{H}-12), 2.63(1 \mathrm{H}, \mathrm{m}, \mathrm{H}-12)$, in combination with ${ }^{1} \mathrm{H}-{ }^{1} \mathrm{H}$ COSY cross peak of $\mathrm{H}-11$ with $\mathrm{H}-12$ and $\mathrm{H}-9$, indicated that 3-oxobutyl was linked to C-9. On the basis of the above evidences and related literature [13], compound 4 was established as 14,15-dinor-3 $\beta$-hydroxy-7-labden-13-one.

Chinese herbal medicines produce a wide variety of secondary metabolites, which can be exploited as potential anticancer agents. Previous chemical investigations on S. emodi revealed the presence of aryltetralin lactone and tetrahydrofuranoid lignans $[2,3,7,8,10]$, flavonoids $[1,6,9,11,20]$, steroids [21], and phenolics [22]. Cytotoxic activities of some isolated S. emodi constituents have been shown in various cancer cell lines. In the HeLa and KB cell lines, deoxypodphyllotoxin was about 579 and 1123 times more toxic than etoposide, respectively [10]. Sinolignan $C$ displayed cytotoxicity against the $\mathrm{KB}$ cell line and was more cytotoxic than etoposide [12]. 3-Methoxyquercetin showed cytotoxicity against the MCF-7 and HepG2 cell lines, with $\mathrm{IC}_{50}$ values of 3.14 and $2.08 \mu \mathrm{M}$, respectively [11]. 
All of the isolated labdane diterpenoids were evaluated for cytotoxic activities against the MCF-7 and HepG2 cell lines (Table 3). Compound 3 was more cytotoxic than 5-fluorouracil, whereas compounds 1, 2 and 4 displayed no cytotoxicity against MCF-7 and HepG2 cell lines. Compounds 1-4 have the same structural skeleton, so the variation in cytotoxicity between them indicates a free hydroxyl group at C-15 was structurally required for the cytotoxity against the MCF-7 and HepG2 cells lines. Esterification at C-15 drastically reduced the cytotoxic activity of the parent compound 3 . These results revealed the potential of compound 3 as an ideal antitumor lead compound.

Table 3. Cytotoxicities of compounds 1-4 against MCF-7 and HepG2 cell lines ( $\left.\mathrm{IC}_{50}, \mu \mathrm{M}\right)$.

\begin{tabular}{cccccc}
\hline Compound & MCF-7 & HepG2 & Compound & MCF-7 & HepG2 \\
\hline $\mathbf{1}$ & $74.6 \pm 5.5$ & $63.5 \pm 6.2$ & $\mathbf{3}$ & $5.73 \pm 0.46$ & $3.85 \pm 0.29$ \\
$\mathbf{2}$ & $88.3 \pm 7.1$ & $75.2 \pm 6.8$ & $\mathbf{4}$ & $50.2 \pm 5.0$ & $39.1 \pm 4.7$ \\
5-Fluorouracil & $6.74 \pm 0.52$ & $5.18 \pm 0.40$ & & & \\
\hline
\end{tabular}

\section{Experimental Section}

\subsection{General Procedures}

The IR spectra were measured on a Tensor 27 Fourier transform infrared (FTIR) spectrometer (Bruker Optics, Ettlingen, Germany) as KBr discs. The 1D and 2D NMR spectra were recorded on an AC (E)-500 spectrometer(Bruker Biospin, Fallanden, Switzerland) using TMS as an internal standard. HR-ESI-MS was determined on a microTOF-Q instrument (Bruker Daltonics, Billerica, MA, USA). Optical rotations were measured on an Autopol IV Digital Polarimeter (Rudolph Research Analytical, Hackettstoun, NJ, USA). The chromatographic silica gel (200-300 mesh) was obtained from Qingdao Ocean Chemical Factory (Qingdao, China). ODS $(50 \mu \mathrm{m})$ was produced from YMC Co. Ltd. (Kyoto, Japan). Sephadex LH-20 was produced by Amersham Pharmacia Biotech (Uppsala, Sweden). Chemical reagents for isolation were of analytical grade and purchased from Tianjin Siyou Co., Ltd. (Tianjin, China). Biological reagents were from Sigma Company (St. Louis, MO, USA). Human heptocellular (HepG2) and breast (MCF-7) cell lines were from Institute of Materia Medica, Chinese Academy of Medical Sciences and Peking Union Medical College (Beijing, China).

\subsection{Plant Material}

The plant material was collected from Deqin, Yunnan Province, China, in September 2013, and identified by Prof. Cheng-Ming Dong as the fruits of S. emodi, according to the Chinese Traditional Medicine Dictionary [23]. A voucher specimen (SE 20130929) was deposited at the School of Pharmacy, Henan University of Traditional Chinese Medicine.

\subsection{Extraction and Isolation}

The dried fruits of $S$. emodi were ground into a power $(9.1 \mathrm{~kg})$, and refluxed with $95 \%$ $\mathrm{EtOH}(3 \times 20 \mathrm{~L})$. The filtrate was concentrated under reduced pressure to yield a dark brown residue $(1.6 \mathrm{~kg})$. The residue was suspended in water $(3.2 \mathrm{~L})$ and partitioned with petroleum ether (PE,


extract $(400.05 \mathrm{~g})$ was fractionated using silica gel column chromatography $(\mathrm{CC}, 20 \times 140 \mathrm{~cm})$ with a gradient of $\mathrm{PE}\left(60-90^{\circ} \mathrm{C}\right)$-acetone. The fractions were combined into eleven main fractions C1-11 based on TLC results. Fraction C3 (5.02 g) was chromatographed over open ODS $(2.5 \times 45 \mathrm{~cm})$, eluted by methanol- $\mathrm{H}_{2} \mathrm{O}$ (20: 80 to 85 : 15$)$ to yield subfractions C-3-1 C $-3-3$. Subfraction C $-3-3$ (0.95 g) was further submitted to silica gel CC $(1.0 \times 25 \mathrm{~cm})$ eluted by PE-acetone (100: 20) to give 1 (7.8 $\mathrm{mg})$ and 2 (4.6 mg). Fraction C4 (6.95 g) was subjected to Sephadex LH-20 CC (2.0 $\times 90 \mathrm{~cm})$ eluted by methanol to yield subfractions C4-1 and C4-2. Subfractions C4-1 (1.74 g) was separated by open ODS $(2.0 \times 40 \mathrm{~cm})$ eluted by methanol- $\mathrm{H}_{2} \mathrm{O}$ (40: 60 to $\left.80: 20\right)$ to give 3 (20.8 $\mathrm{mg}$ ) and 4 (5.2 $\mathrm{mg}$ ). 


\subsection{Spectroscopic and Physical Data}

Sinoditerpene A (1). Sticky oil; $[\alpha]_{D}^{25}-12.4$ ( c 0.14, $\left.\mathrm{CHCl}_{3}\right)$; IR (KBr) $v_{\max } 3464,2967,2930,2855,1737 \mathrm{~cm}^{-1}$; HR-ESI-MS (positive): $m / z 443.2771[\mathrm{M}+\mathrm{Na}]^{+}$(calcd for $\mathrm{C}_{25} \mathrm{H}_{40} \mathrm{O}_{5} \mathrm{Na}, 443.2773$ ); $\mathrm{NMR}$ data $\left(\mathrm{CDCl}_{3}\right)$, see Tables 1 and 2.

Sinoditerpene B (2). Sticky oil; $[\alpha]_{D}^{25}-9.5$ ( $\left.c 0.16, \mathrm{CHCl}_{3}\right)$; IR (KBr) $v_{\max } 3456,2956,2924,2853,1734,1718$; HR-ESI-MS (positive): $m / z 559.3249[\mathrm{M}+\mathrm{Na}]^{+}$(calcd for $\mathrm{C}_{30} \mathrm{H}_{48} \mathrm{O}_{8} \mathrm{Na}, 559.3247$ ); $\mathrm{NMR}$ data $\left(\mathrm{CDCl}_{3}\right)$, see Tables 1 and 2.

\subsection{Alkali Hydrolysis}

Compound $1(6 \mathrm{mg})$ was refluxed with $4 \mathrm{~N}$ alcoholic $\mathrm{KOH}(5 \mathrm{~mL})$ for $1 \mathrm{~h}$. The resulting liquid was neutralized by $1 \mathrm{~N} \mathrm{HCI} \mathrm{until} \mathrm{pH} 7$, and concentrated under reduced pressure, and then extracted with $\mathrm{CH}_{2} \mathrm{Cl}_{2}(10 \mathrm{~mL} \times 3)$ after $10 \mathrm{~mL}$ water was added. The organic phase was washed with water, dried over $\mathrm{Na}_{2} \mathrm{SO}_{4}$ and concentrated in vacuo. The residue was chromatographed on silica gel (PE-acetone 100:7-100:20) to obtain the hydrolyzed target compound.

\subsection{Cytotoxicity Asssay}

Tumor cells were maintained in RPMI-1640 medium containing 10\% heat-inactivated fetal bovine serum, penicillin (100 units $/ \mathrm{mL})$, streptomycin $(100 \mu \mathrm{g} / \mathrm{mL})$ under humidified air with $5 \% \mathrm{CO}_{2}$ at $37^{\circ} \mathrm{C}$. Exponentially growing cells were seeded into 96-well tissue culture-treated plates and precultured for 1 day. The cytotoxic activities of isolated compounds were tested against MCF-7 and HepG2 cell lines, using an established MTT assay protocol [10]. 5-fluorouracil was used as the positive control.

\section{Conclusions}

Further phytochemical studies on S. emodi resulted in the isolation of two new labdane diterpenes 1 and 2 and two known analogues 3 and 4 . All the labdane diterpenoids contained 7(8) and 13(14) double bonds. Isolation of diterpenoids from $S$. emodi is reported here for the first time, which also enriches our knowledge about the chemical diversity of this plant. Compound $\mathbf{1}$ is the first reported example of a labdane diterpene with 7(8) and 13(14) double bonds exhibiting cytotoxicity in the MCF-7 and HepG2 cell lines. As an antitumor lead compound, further investigations are necessary to explore the structure-activity relationship and lead optimization. Our research demonstrated that the fruits of S. emodi have chemopreventive potential as a herbal medicine and its labdane diterpenes are partly responsible for the observed potency. In addition, these results will broaden the application field of S. emodi.

Supplementary Materials: Supplementary materials can be accessed at: http:/ /www.mdpi.com/1420-3049/21/ 4/434/s1.

Acknowledgments: This work was supported by the National Natural Science Foundation of China (No. 31300284, 21402044), Basic Science Foundation of Henan University of Traditional Chinese Medicine (No. 2014KYYWF-QN26), Foundation of Henan Province for Excellent Young Teachers of Colleges and Universities (No. 2015GGJS-096), and Doctoral Science Foundation of Henan University of Traditional Chinese Medicine (No. BSJJ2011-13).

Author Contributions: Yan-Jun Sun and Tao Liu designed research; Mei-Ling Gao, Yan-Li Zhang, Jun-Min Wang, Ya Wu and Yu Wang performed research and analyzed the data; Yan-Jun Sun wrote the paper. All authors read and approved the final manuscript.

Conflicts of Interest: The authors declare no conflict of interest.

\section{References}

1. Sun, Y.J.; Sun, Y.S.; Chen, H.; Hao, Z.Y.; Wang, J.M.; Guan, Y.B.; Zhang, Y.L.; Feng, W.S.; Zheng, X.K. Isolation of two new prenylated flavonoids from Sinopodophyllum emodi fruit by silica gel column and high-speed counter-current chromatography. J. Chromatogr. B 2014, 969, 190-198. [CrossRef] [PubMed] 
2. Zhao, C.Q.; Cao, W.; Nagatsu, A.; Ogihara, Y. Three new glycosides from Sinopodophyllum emodi (Wall.) Ying. Chem. Pharm. Bull. 2001, 49, 1474-1476. [CrossRef] [PubMed]

3. Zhao, C.Q.; Zhu, Y.Y.; Chen, S.Y.; Ogihara, Y. Lignan glucoside from Sinopodophyllum emodi and its cytotoxic activity. Chin. Chem. Lett. 2011, 22, 181-184. [CrossRef]

4. Yang, X.Z.; Shao, H.; Zhang, L.Q.; Zhou, C.; Xuan, Q.; Yang, C.Y. Present situation of studies on resources of podophyllotoxin. Chin. Tradit. Herbal Drugs 2001, 32, 1042-1044.

5. Shi, X.L.; Li, X.W.; Liu, J.B.; Zhou, H.Y.; Zhang, H.Q.; Jin, Y.R. Lignan extraction from the roots of Sinopodophyllum emodi Wall by matrix solid phase dispersion. Chromatographia 2010, 72, 713-717. [CrossRef]

6. Kong, Y.; Xiao, J.J.; Meng, S.C.; Dong, X.M.; Ge, Y.W.; Wang, R.F.; Shang, M.Y.; Cai, S.Q. A new cytotoxic flavonoid from the fruit of Sinopodophyllum hexandrum. Fitoterapia 2010, 81, 367-370. [CrossRef] [PubMed]

7. Zhao, C.Q.; Huang, J.; Nagatsu, A.; Ogihara, Y. Two new podophyllotoxin glucosides from Sinopodophyllum emodi (Wall.) Ying. Chem. Pharm. Bull. 2001, 49, 773-775. [CrossRef] [PubMed]

8. Zhao, C.Q.; Nagatsu, A.; Hatano, K.; Shirai, N.; Kato, S.; Ogihara, Y. New lignin glycosides from Chinese medicinal plant, Sinopodophillum emodi. Chem. Pharm. Bull. 2003, 51, 255-261. [CrossRef] [PubMed]

9. Sun, Y.J.; Pei, L.X.; Wang, K.B.; Sun, Y.S.; Wang, J.M.; Zhang, Y.L.; Gao, M.L.; Ji, B.Y. Preparative isolation of two prenylated biflavonoids from the roots and rhizomes of Sinopodophyllum emodi by Sephadex LH-20 column and high-speed counter-current chromatography. Molecules 2016, 21. [CrossRef]

10. Sun, Y.J.; Li, Z.L.; Chen, H.; Liu, X.Q.; Zhou, W.; Hua, H.M. Three cytotoxic arytetralin lignans from Sinopodophyllum emodi. Bioorg. Med. Chem. Lett. 2011, 21, 3794-3797. [CrossRef] [PubMed]

11. Sun, Y.J.; Hao, Z.Y.; Si, J.G.; Wang, Y.; Zhang, Y.L.; Wang, J.M.; Gao, M.L.; Chen, H. Prenylated flavonoids from the fruits of Sinopodophyllum emodi and their cytotoxic activities. RSC Adv. 2015, 5, 582736-582742. [CrossRef]

12. Sun, Y.J.; Li, Z.L.; Chen, H.; Liu, X.Q.; Zhou, W.; Hua, H.M. Four new cytotoxic tetrahydrofuranoid lignans from Sinopodophyllum emodi. Planta Med. 2012, 78, 480-484. [CrossRef] [PubMed]

13. Urones, J.G.; Marcos, I.S.; Oliva, I.M.; Garrido, N.M.; Hagget, J.; Humphreys, V.M. Labdane diterpenes from Halimium viscosum. Phytochemistry 1995, 38, 663-666. [CrossRef]

14. Lu, L.Q.; Cui, H.Y.; Zhang, L.C.; Liu, Q.; Qin, B. Chemical constituents from the aerial parts of Stellera chamaejasme L. Nat. Prod. Res. Dev. 2014, 26, 53-55.

15. Ferracini, V.L.; Roewer, I.; Gao, F.; Mabry, T.J. Ent-Labdane diterpenoids, tremetone and chromene derivatives and flavonoids from Ophryosporus heptanthus. Phytochemistry 1989, 28, 1463-1465. [CrossRef]

16. Zdero, C.; Bohlmann, F. Macrolide diterpenes and other ent-labdanes from Corymbium villosum. Phytochemistry 1988, 27, 227-231. [CrossRef]

17. Toki, M.; Ooi, T.; Kusumi, T. Sesterterpenoids and diterpenoids of the wax excreted by a scale insect, Ceroplastes pseudoceriferus. J. Nat. Prod. 1999, 62, 1504-1509. [CrossRef] [PubMed]

18. Purushothaman, K.K.; Sarada, A.; Saraswathy, A.; Connolly, J.D. Sempervirenic acid, a diterpene acid from Solidago sempervirens. Phytochemistry 1983, 22, 1042-1043. [CrossRef]

19. Cui, C.W.; Sun, C.L.; Chen, Q.C.; Zou, X.H.; Huang, X.M.; Chen, H.F. Preliminary study on chemical constituents seperated from Cayratia japonica. Chin. J. Chin. Mater. Med. 2012, 37, 2906-2909.

20. Sun, Y.J.; Zhou, W.; Chen, H.; Li, Z.L.; Hua, H.M. Isolation and identification of flavonoids from the roots and rhizomes of Sinopodophyllum emodi. J. Shenyang Pharm. Univ. 2012, 29, 185-189.

21. Sun, Y.J.; Li, Z.L.; Chen, H.; Zhou, W.; Hua, H.M. Study on chemical constituents from the roots and rhizomes of Sinopodophyllum emodi. J. Chin. Med. Mat. 2012, 35, 1607-1609.

22. Sun, Y.J.; Zhou, W.; Chen, H.; Li, Z.L.; Hua, H.M. Phenols from roots and rhizomes of Sinopodophyllum emodi. Chin. Tradit. Herbal Drugs 2012, 43, 226-229.

23. Jiangsu New Medical College. Chinese Traditional Medicine Dictionary; Shanghai Science and Technology Publishing House: Shanghai, China, 1977; pp. 1791-1792.

Sample Availability: Samples of the compounds 1-4 are available from the authors.

(C) 2016 by the authors; licensee MDPI, Basel, Switzerland. This article is an open access article distributed under the terms and conditions of the Creative Commons by Attribution (CC-BY) license (http://creativecommons.org/licenses/by/4.0/). 